\title{
A REGIONÁLIS KÖZPONTOK SZEREPÉNEK VÁLTOZÁSA MAGYARORSZÁG VÁROSHÁLÓZA- TÁBAN A SZABAD KIRÁLYI VÁROSOKTÓL A NUTS RÉGIÓKÖZPONTOKIG
}

\author{
(Changing Role of the Regional Centres from Libera Regiae \\ Civitas to NUTS Regional Centres)
}

\section{CSOMÓS GYÖRGY}

\begin{abstract}
Kulcsszavak:
szabad királyi város törvényhatósági jogú város megyei jogú város regionális centrum régióközpont pólusváros terïletfejlesztési koncepció

Jelen tanulmány a magyarországi regionális centrumok városhálózatban betöltött pozicióváltozásait követi nyomon a szabad királyi városoktól a NUTS 2 tervezési-statisztikai régiók kialakitásáig. A nagyvárosok szempontjából napjaink egyik legfontosabb kérdése, hogy a regionális centrumok (egyúttal pólusvárosok) lesznek-e a NUTS 2 régiỏk tényleges központjai, vagyis az évszázados fejlódéssel kialakult centrumokkal szemben létezik-e más alternativa?
\end{abstract}

Magyarország nagyvárosainak közigazgatási besorolása, politikai megítélése az elmúlt másfél évszázad során számtalanszor változott, ok-okozat kérdéseként merült fel a nagyváros meghatározás is. A változásokat befolyásolták a városok „lobbi” tevékenységei, az aktuális politikai célok, a kijelölt fejlesztési irányok, a tudományos paradigmák és sajátos magyar elemként az ország területi változásai. A 19. század városhierarchiájának csúcsán a szabad királyi városok, majd a törvényhatósági jogú városok álltak, a városhálózatban betöltött szerepük azonban sok esetben nem következett rangjukból. A 20. század térszerkezeti folyamatait az ország területi változásai és az éppen aktuális politikai irányzat racionális vagy irracionális fejlesztési elképzelései határozták meg. A rendszerváltozást követó közigazgatási reformok megszüntették a hierarchikus berendezkedést, valamennyi település önálló entitássá vált, azonban a városhálózat homogén tömegéből szigetszerủen emelkedtek ki a megyei jogú városok. A demokratikus államberendezkedéssel kialakult közigazgatási struktúrában új elemként jelentek meg az Európai Unió regionális politikáját követő, több megyét átfogó NUTS 2 tervezési-statisztikai régiók. A városhálózat csomópontjaiban elhelyezkedő regionális centrumok több száz éves fejlődés eredményeként jöttek létre, azonban a régióközpontok kijelölése elsösorban a politikai akarat függvénye. 
Csomós György : A regionális központok szerepének változása Magyarország városhálózatában

a szabad királyi városoktól a NUTS régióközpontokig. Tér és Társadalom 23. évf. 2009/2. 97-111. p.

\section{Magyarország nagyvárosainak megitélése a 19. század közepétöl a trianoni határváltozásokig}

Az 1848. márciusi-áprilisi törvényekig a területi adózás alapegységeit és az általános közigazgatás hatóságait a nemesi vármegyerendszer testesítette meg (Hajdú 1996). A nemesi vármegye (comitatus) önkormányzata önmagában alapvetően demokratikus intézményként funkcionált, azonban sem az ország, sem a vármegye városai felé nem érvényesült a demokratikus jelleg. Mint önkormányzati szerv a nemesi vármegye belügyként kezelte a közigazgatást, a bíráskodást és az itélkezést, az adóztatást és a rendfenntartást, a megyék követeik révén az országgyülést is befolyásolták (Hajdú 2005).

A nemesi vármegyék irányítása és befolyása nem terjedt ki a szabad királyi városokra (libera regiae civitas), amelyek a városi kiváltságok legfontosabb formáját jelentették. A szabad királyi városok közvetlenül a királyhoz tartoztak, mentesültek a feudális bíráskodás és az adózás alól, polgárai csak a királynak és a városnak fizettek adót. A szabad királyi város státusz kivívása a király, a megye nemessége és az egyház, valamint a városok polgársága közötti harc eredménye volt, egyúttal a város fejlődésének záloga. Az 1867-es kiegyezésig a szabad királyi városok száma 81-re nött, a mai Magyarország területén azonban csak 12 város nyerte el a rangot, köztük Buda, Debrecen, Győr, Pest, Pécs, Szeged és Székesfehérvár (Beluszky 2005).

1825-ben Magyarország legnagyobb lakosságszámú városa Debrecen volt több mint 45000 lakosával, az egyesítés elötti Pest és Buda önmagukban kisebbnek számítottak. Gyimesi Sándor népességszámra, ipari és kereskedelmi szerepkör fejlettségére, igazgatási és oktatási intézmények meglétére alapozott városiassági értéke szerint Pest, Debrecen, Buda, Györ és Szeged állt a városi szerepkör volumenének hierarchikus rangsora élén (Beluszky 2003). Bácskai Vera és Nagy Lajos a piacközponti szerepkört tekintette a rangsor meghatározó elemének, számításaik során a kereskedelmi vonzáskörzet volt a meghatározó (Bácskai-Nagy 1984). Ennek eredménye, hogy a várostalan területek nagyvárosai, elsősorban az alföldi városok, így Debrecen, Kecskemét és Szeged a rangsor végére kerültek. Bácskai Vera szerint a regionális központok és a megyeszékhelyek külön kategóriát képeztek, több város is rendelkezett regionális szintủ intézményekkel, még sem volt megyeszékhely város (Bácskai 2006).

$\mathrm{Az}$ 1848. évi XXIII. törvénycikk, valamint az 1848. évi XVI. törvénycikk alapjaiban változtatta meg a közigazgatás évszázados gyakorlatát. Az Országgyülés népképviseleti alapon szerveződésével a nemesi vármegye joga a követküldésre elveszett, a megye kikerült a törvényhozás szereplöinek köréből. A szabad királyi városok a törvénybe foglaltak szerint önálló köztörvényhatóságok, minden tekintetben függetlenekké váltak a megyétöl. A törvény kategorizálta a városokat, elsőként került a jogalkotásban említésre a nagyváros meghatározás: 4. § „Olly városok, mellyekben 12,000 lakosnál kevesebb vagyon, kis városoknak, mellyekben 12,000 lakosnál több, de 30,000 lakosnál kevesebb vagyon, közép városoknak, és mellyekben 30,000 lakosnál 
Csomós György : A regionális központok szerepének változása Magyarország városhálózatában a szabad királyi városoktól a NUTS régióközpontokig. Tér és Társadalom 23. évf. 2009/2. 97-111. p.

több vagyon, nagy városoknak neveztetnek." A törvény értelmében a mai Magyarország területérỏl nagyvárosnak minősült Pest-Buda, Debrecen, Szeged és Kecskemét.

Az 1867-es kiegyezést követően átalakult az államstruktúra, az Osztrák-Magyar Monarchia létrejöttével az abszolutizmus merev közigazgatási rendszere felbomlott. Az 1870. évi XLII. törvénycikk értelmében elválasztották a közigazgatást a bíráskodástól, értelmezték a törvényhatóságok helyzetét és jogállását, meghatározták feladatait és intézményrendszerét. A köztörvényhatóságok gyakorolják az önkormányzati jogokat, közvetítik az állami közigazgatást, közérdeküségük révén országos ügyekkel is foglalkozhatnak, megfogalmazott véleményüket a kormány, az országgyülés és más törvényhatóság elé terjeszthetik. Az 1876. évi XX. törvénycikk, az 1876. évi XXXIII. törvénycikk, valamint az 1877. évi I. törvénycikk megszüntette a feudális eredetü önkormányzatokat, és rögzítette a megyebeosztást. A törvények értelmében a korábbi 81 szabad királyi városból mindössze 25 maradt törvényhatósági jogú város (Budapest és Fiume sajátos helyzete mellett), a szabad királyi város rang a feudális korszak örökségeként élhetett tovább tartalom nélkül. A törvényhatósági joggal már nem rendelkezö városokat a megyék alá sorolták, az új közigazgatási rendszerben Debrecen, Nyíregyháza és Szolnok is megyeszékhelyi rangot kapott. Az 1886. évi XXI. törvénycikk és az 1892. évi XXVI. törvénycikk pontosan rögzíti a törvényhatósági joggal felruházott városok sorát. Ennek értelmében a 25 törvényhatósági jogú városból 10 maradt a mai Magyarország területén: Baja, Debrecen, Györ, Hódmezővásárhely, Kecskemét, Komárom, Pécs, Sopron, Szeged és Székesfehérvár. A törvényhatósági jogú városok közül Baja, Hódmezövásárhely és Kecskemét kivételével valamennyi város egyben szabad királyi város is volt, az 1872. évi XXXVI. törvénycikk által egyesített Budapest pedig, mint az ország fỏvárosa külön státuszt képviselt (Kovács-Katus 1987).

A trianoni határmódosításokig valamennyi mai regionális központ törvényhatósági joggal rendelkezett, Debrecen, Győr, Miskolc, Pécs, Szeged és Székesfehérvár közigazgatási értelemben a városhierarchia élére került.

Beluszky Pál 1990-es vizsgálatában a századfordulón kialakult városhierarchiát a városi alapfunkciók mennyisége és sokfélesége alapján állapította meg (Beluszky 1990). Véleménye szerint a települések hierarchikus rangja a városi alapfunkciók differenciáltságát, az ellátott feladatok szintjét, az ellátott szerepkör gyakoriságát fejezi ki. Az így kialakított rangsor hat hierarchia szintet tartalmaz. A városhierarchia élén az 1873-ban Óbuda, Buda és Pest egyesítésével létrejött Budapest áll, amely az 1867-es kiegyezés után a közel 20 millió lakosú Magyarország fövárosa lett, az Osztrák-Magyar Monarchián belül Bécs ellenpólusa (Györffy 1997). A századfordulóra Budapest lakossága már 12-szer nagyobb volt, mint a hierarchiában utána következö Zágráb lakossága, és nyolcszor, mint a második legnépesebb város, Szeged lakossága. A föváros városhálózatban betöltött súlya már a trianoni határváltozásokat megelőzően is sokkal jelentősebb volt, mint a regionális centrumoké.

A regionális központok hierarchia szintjeit Beluszky Pál véleménye szerint két szempont szerint lehet megközelíteni, egyrészt a városi szerepkörök differenciáltsága (jogállás, funkció, hierarchia, városi társadalmi viszonyok) alapján, másrészt a városi funkciók mennyiségi értékei alapján (Beluszky 1990; 2003). Mindkét esetben 
ugyanaz a 10 város alkotja a regionális centrumok körét: Zágráb, Pozsony, Kolozsvár, Szeged, Kassa, Debrecen, Pécs, Temesvár és Arad (1. táblázat). Regionális szerepkört változó mértékben más városok is elláttak, de összességében nem a regionális központok szintjén, például Miskolc, Györ vagy Székesfehérvár.

\section{TÁBLÁZAT}

A magyarországi regionális centrumok hierarchiája 1900-ban és 1910-ben (Hierarchy of the Regional Centres in 1900 and in 1910)

\begin{tabular}{|c|c|c|c|}
\hline Szám & Város & Hierarchia szint & $\begin{array}{c}\text { Lakosság- } \\
\text { szám } \\
\text { 1900-ban (fó) }\end{array}$ \\
\hline 1. & Budapest & Föváros $(1900,1910)$ & 716476 \\
\hline 2. & Zágráb & $\begin{array}{l}\text { Teljes értékü regionális centrum } \\
\qquad(1900,1910)\end{array}$ & 57690 \\
\hline 3. & Kolozsvár & $\begin{array}{l}\text { Teljes értékü regionális centrum } \\
\qquad(1900,1910)\end{array}$ & 46670 \\
\hline 4. & Pozsony & $\begin{array}{l}\text { Teljes értékü regionális centrum } \\
\qquad(1900,1910)\end{array}$ & 61537 \\
\hline 5. & Szeged & $\begin{array}{l}\text { Teljes értékủ regionális centrum } \\
\qquad(1900) \\
\text { Részleges regionális centrum (1910) }\end{array}$ & 90270 \\
\hline 6. & Kassa & $\begin{array}{l}\text { Teljes értékủ regionális centrum } \\
\qquad(1900,1910)\end{array}$ & 35586 \\
\hline 7. & Debrecen & $\begin{array}{l}\text { Részleges regionális centrum (1900) } \\
\text { Teljes értékü regionális centrum } \\
(1910)\end{array}$ & 72351 \\
\hline 8. & Pécs & $\begin{array}{c}\text { Részleges regionális centrum (1900, } \\
1910)\end{array}$ & 42252 \\
\hline 9. & Temesvár & $\begin{array}{l}\text { Részleges regionális centrum (1900) } \\
\text { Teljes értékü regionális centrum } \\
\qquad(1910)\end{array}$ & 49624 \\
\hline 10. & Nagyvárad & $\begin{array}{l}\text { Részleges regionális centrum (1900, } \\
1910)\end{array}$ & 47018 \\
\hline 11. & Arad & $\begin{array}{c}\text { Részleges regionális centrum (1900, } \\
1910)\end{array}$ & 53694 \\
\hline 12. & Miskolc & $\begin{array}{l}\text { Teljes értékủ fejlett megyeszékhely } \\
\qquad(1900)\end{array}$ & 40833 \\
\hline 13. & $\begin{array}{l}\text { Székes- } \\
\text { fehérvár }\end{array}$ & $\begin{array}{l}\text { Teljes értékủ fejlett megyeszékhely } \\
\qquad(1900)\end{array}$ & 30451 \\
\hline 16. & Györ & $\begin{array}{l}\text { Teljes értékü fejlett megyeszékhely } \\
\qquad(1900) \\
\text { Részleges regionális centrum (1910) }\end{array}$ & 27758 \\
\hline
\end{tabular}

Forrás: Beluszky 2003. 
Csomós György : A regionális központok szerepének változása Magyarország városhálózatában a szabad királyi városoktól a NUTS régióközpontokig. Tér és Társadalom 23. évf. 2009/2. 97-111. p.

TÉT XXIII. évf. 2009 - 2

Tértörténet

101

A teljes értékủ regionális központok közül Zágráb (Horvát-Szlavónország), Kolozsvár (Erdély), Pozsony és Kassa (Felvidék) valójában országrészközpontok voltak, ellentétben Szegeddel, amelynek megítélése a legbizonytalanabb. Fejlödése szempontjából meghatározó Temesvár és Arad közelsége. A Bánát és Dél-Erdély központjai a 20. század elejére már nagyobb gazdasági háttérrel rendelkeztek, mint Szeged. 1910-re a regionális központok sora módosult, Zágráb, Kolozsvár, Pozsony és Kassa továbbra is teljes értékủ regionális központok maradtak, de közéjük lépett Debrecen és Temesvár. Szeged a részleges regionális központok csoportjába került Nagyvárad, Pécs, Arad, a felzárkózó Győr és Brassó mellé. Budapest változatlanul a legerősebb város maradt, 1910-re közel 900 ezer lakosával jelentősen elmaradva a 2 milliós Bécstől, de messze kiemelkedve a regionális központok közül (Hajdú 2005).

A trianoni határváltozásokat megelőzỏ években a mai Magyarország területén regionális központoknak tekintett városok mindegyike rendelkezett a legfontosabb közigazgatási besorolással, a törvényhatósági joggal, mellette Debrecen, Győr, Pécs, Szeged és Székesfehérvár egyúttal szabad királyi városok is voltak. A városok hierarchikus rangsorában 1910-ben csak Debrecen töltötte be teljes értékủen a regionális központ szerepkört, Györ, Pécs és Szeged részlegesen ugyan, de megfelelt a regionális központ státusznak, azonban Miskolc és Székesfehérvár teljes értékủ fejlett megyeszékhely maradt.

\section{A városhálózat változása a két világháború között}

Az I. világháborút lezáró békeszerződések részeként 1920. június 4-én Versaillesban aláírásra került a „Trianoni békeszerződés”, melynek következményeként az Osztrák-Magyar Monarchia felbomlott, a Magyar Királyság pedig elveszítette $324411 \mathrm{~km}^{2}$ összterületének (Horvátországgal együtt) közel háromnegyedét (71,34\%), lakosságának majd kétharmadát $(63,6 \%)$. A trianoni határváltozások után Magyarország területe $92963 \mathrm{~km}^{2}$-re módosult, lakossága alig haladta meg a 7,6 millió föt (Palotás 1990).

A területi változások következtében 1910-ben a teljes értékủ és részleges regionális központok közül Zágráb (Horvátország), Kolozsvár, Temesvár, Nagyvárad, Arad és Brassó (Románia), Pozsony és Kassa (Csehszlovákia) elcsatolásra kerültek. A Magyarországon maradt Debrecen elveszítette vonzáskörzetének jelentős részét, Győr, Pécs és Szeged pedig korábban sem tartozott a teljes értékü regionális központok közé. A városhálózat új struktúrájában Budapest súlya aránytalanul dominánssá vált, a megmaradt regionális központok a különböző állami fejlesztések ellenére sem tudták ellensúlyozni a főváros megnövekedett szerepét (Hajdú 2005).

A két világháború közötti időszak revíziós politikája a közigazgatásra is hatást gyakorolt, a területi változásokat és az államhatárok radikális módositását átmenetinek kezelték, következésképpen jelentős közigazgatási reformot nem is hajtottak végre. A politikai gondolkodással ellentétben a területfejlesztési elképzelések min- 
Csomós György : A regionális központok szerepének változása Magyarország városhálózatában

a szabad királyi városoktól a NUTS régióközpontokig. Tér és Társadalom 23. évf. 2009/2. 97-111. p.

102 Tértörténet

TÉT XXIII. évf. 2009

den tekintetben igazodtak a megváltozott körülményekhez. Prinz Gyula alapvetöen közlekedésföldrajzi, kisebb részt településföldrajzi meggondolásokon alapuló közigazgatási struktúrája hét regionális közigazgatási központtal számolt, amelyek Budapest, Debrecen, Győr, Pécs, Szeged Miskolc és Székesfehérvár voltak (Hajdú 2005). Magyary Zoltán az 1930-as években a közigazgatás racionalizálásáról alkotott elképzeléseiben bázisként 14 megyét határozott meg, Baja, Békéscsaba, Budapest, Debrecen, Győr, Hatvan, Kaposvár, Miskolc, Nyíregyháza, Pécs, Szeged, Székesfehérvár, Szolnok és Szombathely központokkal. Prinz Gula és Magyary Zoltán megállapításait és elképzeléseit figyelembe véve Hantos Gyula a köz- és szakigazgatási rendszerek területi struktúrája alapján hét régiót határozott meg, melyek központjaiként Budapest, Debrecen, Györ, Miskolc, Pécs, Szeged és Szombathely lett megjelölve. Frisnyák Sándor szerint az 1930-as években Budapest ellenpólus városai a regionális centrumoknak tartott Debrecen, Györ, Pécs és Szeged, valamint ipari termelésük alapján Miskolc és Székesfehérvár voltak (Frisnyák 1995). A korábbiaktól eltérő elvek mentén, de lényegében hasonlóan fogalmazta meg Kaffka Péter, a Fővárosi Közmunkák Tanácsának mérnöke müszaki-gazdasági alapokon nyugvó országrendezését. A megyebeosztás alapjának „az értelmes múszaki felosztást" kell tekinteni, vagyis a nyolc nagymegye (gyakorlatilag régió) közlekedésföldrajzi alapon a Budapestet övező központi megyét „legyezöszerủen” kísérő hét nagymegye (Kaffka 1932; 1933).

A bécsi döntések $55419 \mathrm{~km}^{2}$-t juttattak vissza az elcsatolt területekből Magyarországnak. A közigazgatás tekintetében az Imrédy Béla vezette kormányzat a jogfolytonosságra helyezte a hangsúlyt, a visszacsatolások utáni megyék és járások a trianoni határváltozások elötti struktúrát vették fel. A városok száma a visszacsatolások és területnyereségek miatt folyamatosan emelkedett, és 1944-re elérte a 81-et. Erdei Ferenc politológus-szociológus szerint az országrendezési elvek lényege, hogy a városi vonzáskörzeteknek megfelelö közigazgatási egységek jöjjenek létre. A közigazgatási struktúra megtartása érdekében tartományi szerepkörü városok kijelölése lenne szükséges, Budapest irányítása mellett Debrecen, Györ, Kassa, Miskolc, Pécs, Szeged és Szombathely (Erdei 1939).

A két világháború közötti időszak területfejlesztési elképzelési megmaradtak elméleti szinten, gyakorlati változás nem történhetett, a közigazgatási struktúra változatlan maradt. A II. világháborút lezáró 1947-es párizsi békeszerződések kisebb eltérésekkel visszaállitották a trianoni határokat, ezzel mintegy véglegesnek tekintve Magyarország területét és határait (Rónai 1989). 
Csomós György : A regionális központok szerepének változása Magyarország városhálózatában a szabad királyi városoktól a NUTS régióközpontokig. Tér és Társadalom 23. évf. 2009/2. 97-111. p.

\section{A nagyvárosok megitélése az államszocializmus idöszakának terület- fejlesztési elképzeléseiben}

A szocializmus időszaka a területi kérdésekre adott válaszok szempontjából nem tekinthető egységesnek. Az aktuális három- és ötéves tervek, a gazdasági elvárások és kényszerek, a politikai elit racionális vagy irracionális gondolkodásmódja éppúgy hatást gyakorolt rá, mint a társadalomban jelentkező feszültségek.

A közigazgatás struktúrájában bekövetkezett változások eredményeként a korảbbi 25 megyét 19 megyére csökkentették, és megszüntették a községi jogállású megyeszékhelyeket, a továbbiakban megyeszékhely csak városi jogú település maradhatott (Kolozsváry-Szamel 1950). Az 1950. évi I. tanácstörvény 24 nagyobb várost a megyei tanácsok, 29 kisebb várost pedig a járási tanácsok alá rendelt, megteremtve ezzel a megye - város, illetve a megye - járás - város hierarchiát, de függetlenítve attól Budapestet. A fövárost körülvevő agglomerációs területből, hét városból és 16 községből létrehozták Nagy-Budapestet, melynek dominanciája a korábbi évekhez képest fokozottabban érvényesült (Dövényi 2003).

A közigazgatási változások mellett az 1950-es években a településhálózat formálódására a leghatározottabban a gazdasági szempontok gyakoroltak hatást. Az I. Ötéves Terv keretében a beruházási javak szükössége miatt a már korábban is nehézipari központnak számító települések fejlesztése történt meg, elsỏsorban a Borsodi Iparvidéken (Kazincbarcika, Miskolc, Ózd), valamint a Bakonyban (Várpalota, Ajka). A feldolgozó ipar központja továbbra is Budapest volt. A Dunántúli-középhegységtől Budapesten keresztủl az Északi-középhegységig hủzódó ipari tengely településeinek fejlesztése (erỏltetett iparosítása) a szocialista várostípus kialakulásához vezetett.

A településhálózatra vonatkozó tervezési irányokat a Népgazdasági Tanács határozta meg, melynek legfontosabb eleme a települések kategorizálása volt (Hajdú 1989). A tervezés eredményeként három településhálózat-fejlesztési alapkategóriát határoztak meg, a különböző alapkategóriákba tartozó településekhez pedig differenciált fejlesztési irányokat rendeltek (2. táblázat). A hierarchia csúcsán, mint osztályon felüli település állt Budapest és a stratégiai szempontból kiemelt, nehézipari központ Miskolc. Az I. osztályú települések körébe kerültek a megyeszékhelyek mellett a korábbi megyeszékhelyek, a fejlettebbnek ítélt városok és a nagyipari fejlesztésre kijelölt települések. A III. kategóriába kerülő 3067 település három alcsoportba került: fejleszthetô telepủlések (III./A), részlegesen fejleszthetö települések (III./B) és nem fejleszthetö települések (III./C).

Az 1950-es években a település- és településhálózat-fejlesztési elképzelések mellett a korábbiaknál radikálisabb közigazgatási reformtervezet is készült. 1953-ban a Magyar Dolgozók Pártja Politikai Bizottsága megvitatta a 10 megyés közigazgatási beosztás lehetőségét, amely - bár nem tudatosan - egyfajta centralizációs törekvést hordozott magában. A reformterv alapvetően közlekedési és a hadászati elvek mentén alakította ki a megyebeosztást, a tervezett megyéket olyan területi-gazdaságiigazgatási alapegységgé kellett fejleszteni, amelyek nagyobb méretủek a korábbiaknál, a megyeszékhelyek pedig távolabb fekszenek a veszélyesnek ítélt határszakaszoktól (Hajdú 1993). 
Csomós György : A regionális központok szerepének változása Magyarország városhálózatában a szabad királyi városoktól a NUTS régióközpontokig. Tér és Társadalom 23. évf. 2009/2. 97-111. p.

Az 1953-as közigazgatási reformterv megmaradt terv szintjén, ugyanakkor 1955-ben a Területszervezési Kormánybizottság egy 12 megyés elképzelést dolgozott ki hasonló elgondolások alapján. A megyerendezés irányelveinek alapja továbbra is a biztonságpolitika volt, azonban a közlekedésföldrajzi izokrón térképek bizonyították, hogy a megyeszékhelyek sorából nem hagyható ki sem Szeged, sem Szombathely (Hajdú 1989). A 12 megyés beosztás tervezetét számos politikai és szakmai vita követte, amelyben meghatározó elem volt (politikai részröl) a megyék és megyeszékhelyek számának csökkentése, valamint (szakmai részről) a közigazgatás racionális szerkezetének megtartása. A viták eredményeként született meg, mintegy kompromisszumos megoldásként a 14 megyés közigazgatási beosztás tervezete.

\section{TÁBLÁZAT}

A községek és városok osztályba sorolása 1951-ben

(Categorization of Villages and Cities in 1951)

\begin{tabular}{ccc}
\hline Osztály & $\begin{array}{c}\text { A besorolt települések } \\
\text { száma }\end{array}$ & $\begin{array}{c}\text { Az összes település } \\
\text { százalékában }\end{array}$ \\
\hline Osztályon felüli & 2 & 0,06 \\
\hline I. osztályú & 73 & 2,27 \\
\hline II. osztályú & & \\
II./A osztályú & 52 & 1,61 \\
II./B osztályú & 29 & 0,90 \\
\hline III. osztályú & & \\
III./A osztályú & 1254 & 38,91 \\
III./B osztályú & 283 & 8,78 \\
III./C osztályú & 1530 & 47,47 \\
\hline Összes település & 3223 & 100 \\
\hline
\end{tabular}

Forrás: Hajdú (1992).

Az egy évtizeden át tervezett közigazgatási reformok a gyakorlati életbe nem kerültek át, az 1960-as évek elején - a törekvések ellenére is - a tradicionálisan nagyvárosnak számító megyeszékhelyek álltak a városhierarchia élén. Beluszky Pál számításai szerint a regionális központok körébe Debrecen, Győr, Pécs és Szeged mellé a tudatosan fejlesztett nehézipari központ, Miskolc is felzárkózott (Beluszky 2003).

Az 1960-as években a közigazgatási változások alapját a megyereformokkal szemben a gazdasági körzetesítés jelentette. 1963-ban elkészült Magyarország Településhálózat-fejlesztési Tanulmányterve, amelyben az igazgatási egységek és a gazdasági körzetek összehangolásával érvényesült a közigazgatási tér komplex tervezése és megjelenítése (Hajdú 2005). A Tanulmánytervben ugyan megfogalmazták a településhálózat örökölt aránytalanságainak megszüntetését és Budapest túlsúlyának csökkentését, azonban az 1950-es évek elképzeléseihez képest lényeges változások nem jelentek meg benne. A régióközpontok száma kilencre emelkedett, a gazdasági körzetek központi városa Debrecen, Györ, Miskolc, Pécs és Szeged maradt, de mellettük Nagykanizsa, Szolnok és Székesfehérvár is regionális központ besorolást kapott. A Településhálózat-fejlesztési Tanulmányterv az állami irányitás központi in- 
Csomós György : A regionális központok szerepének változása Magyarország városhálózatában a szabad királyi városoktól a NUTS régióközpontokig. Tér és Társadalom 23. évf. 2009/2. 97-111. p.

tézményeinek, az Országos Tervhivatalnak és az Építésügyi és Városfejlesztési Minisztériumnak a kompromisszum képtelensége miatt nem valósult meg, ugyanakkor megfelelö alapot szolgáltatott a következỏ évek területfejlesztési irányaihoz.

A korábbi időszak fejlesztési elképzeléseire, de elsősorban a Településhálózatfejlesztési Tanulmánytervre alapozva 1969-ben készült el az Országos Településhálózat-fejlesztési Keretterv, amelyben korántsem új elemként jelentek meg a településkategóriák (3. táblázat).

\section{TÁBLÁZAT}

A települések regionális szerepköre az 1969-es Országos Településhálózatfejlesztési Keretterv szerint

(Regional Role of Settlements in 1969 According to the National Settlement Network Development Framework Plan)

\begin{tabular}{lcc}
\hline \multicolumn{1}{c}{ Regionális szerepkör } & $\begin{array}{c}\text { A besorolt települé- } \\
\text { sek száma }\end{array}$ & $\begin{array}{c}\text { Az összes település } \\
\text { százalékában }\end{array}$ \\
\hline Országos központ & 1 & 0,03 \\
Felsöfokú központ & 7 & 0,22 \\
Részleges felsőfokú központ & 11 & 0,35 \\
Középfokú központ & 66 & 2,08 \\
Részleges középfokú & 39 & 1,23 \\
központ & 123 & 3,87 \\
Kiemelt alsó fokú központ & 524 & 16,49 \\
Alsó fokú központ & 270 & 8,49 \\
Részleges alsó fokú központ & 2137 & 67,24 \\
Falu & 3178 & 100 \\
\hline Összes település & & \\
\hline
\end{tabular}

Forrás: Hajdú (1992).

Az 1970-es évek jelentős változásokat hoztak mind a közigazgatás struktúrájának formálódásában, mind a településhálózat fejlesztésének tervezési irányaiban. Az 1971. évi III. tanácstörvény megszüntette a járások tanácsi szintjét és a megyék irányítása alá sorolta őket, hasonlóan a városokhoz. A megyei jogú város kategória helyett megyei városok jöttek létre, amelyek Debrecen, Győr, Miskolc, Pécs és Szeged voltak.

1971-ben a Minisztertanács jóváhagyta az Országos Településhálózat-fejlesztési Koncepciót (OTK), amely az elkövetkezó évtizedek településfejlesztési irányát is meghatározta, érvényessége elméletileg 2000-ig szólt (1007/1971. [III. 6.] Korm. sz. határozat). Az OTK a korábban alkalmazott gyakorlathoz hasonlóan kategorizálta a településeket, de az alapkategóriák száma messze a legtöbb lett (4. táblázat). 
Csomós György : A regionális központok szerepének változása Magyarország városhálózatában a szabad királyi városoktól a NUTS régióközpontokig. Tér és Társadalom 23. évf. 2009/2. 97-111. p.

106 Tértörténet

TÉT XXIII. évf. 2009

\section{TÁBLÁZAT}

A települések besorolása központi szerepkörük szerint az 1971-es Országos Településhálózat-fejlesztési Koncepció alapján

(Categorization of Settlements by their Regional Role in 1971 According to the National Settlement Network Development Concept)

\begin{tabular}{ccc}
\hline Központi szerepkör & $\begin{array}{c}\text { A besorolt települé- } \\
\text { sek száma }\end{array}$ & $\begin{array}{c}\text { Az összes település } \\
\text { százalékában }\end{array}$ \\
\hline Országos központ & 1 & 0,03 \\
Kiemelt felsőfokú központ & 5 & 0,15 \\
Felsőfokú központ & 7 & 0,22 \\
Részleges felsőfokú központ & 11 & 0,34 \\
Középfokú központ & 65 & 2,02 \\
Részleges középfokú központ & 41 & 1,28 \\
Kiemelt alsó fokú központ & 142 & 4,43 \\
Alsó fokú központ & 530 & 16,52 \\
Részleges alsó fokú központ & 292 & 9,10 \\
Budapesti agglomerációba & 44 & 1,37 \\
tartozó települések & 2071 & 64,54 \\
Egyéb település & 3209 & 100 \\
\hline Összes település & \multicolumn{2}{c}{} \\
\hline
\end{tabular}

Forrás: Hajdú (1992).

A Koncepciónak a területfejlesztés szempontjából egyik legfontosabb eleme a területi kiegyenlitésre törekvés, amellyel Budapest közel egy évszázados városhálózatban betöltött dominanciáját kívánták megszüntetni (Rechnitzer 1998). Az OTK a fớközlekedési hálózat meghatározó csomópontjaiban a tradicionális regionális központokat (Debrecen, Győr, Miskolc, Pécs és Szeged) ellenpólus városokként jelölte meg, azonban a Településhálózat-fejlesztési Tanulmánytervben szereplö kilenc gazdasági körzettel szemben csak öt tervezési-gazdasági körzettel számolt ${ }^{1}$.

Az OTK-t számos bírálat érte annak ellenére is, hogy a gyakorlatban nem került alkalmazásra, elvi megállapításai azonban hosszú évekre meghatározták a településfejlesztési irányokat. Az első szakmai kritika már 1975-ben megfogalmazódott. Bibó István közigazgatási térszervezési elmélete szerint újra kell értelmezni a közigazgatási egységeket és optimalizálni kell a székhelyeket. A területi egységek között olyan hierarchiát kell kialakítani, amelynek során az alsóbb és a felsőbb szintü területi egységek egészben illeszkednek a következő szintü területi egységbe ${ }^{2}$. A területi egységek központjának olyan települést célszerü választani, amelyben a közszolgáltatások mindenki számára elérhetők. Elmélete szerint a hat kerületi székhely több városjárást átfogó területi egység közigazgatási központja legyen, amelynek Budapest, Debrecen, Győr, Miskolc, Pécs és Szeged felel meg (Bibó 1975).

Az 1980-as években az egyetlen jelentös közigazgatási változás a járások megszüntetése és a városkörnyéki beosztás elkészítése volt (Beluszky 1987). A tervezet számos konfliktushoz vezetett a megyék részéröl, mivel a városkörnyéki területi egységek nem vették volna figyelembe a történelmi megyehatárokat. A megyék 
Csomós György : A regionális központok szerepének változása Magyarország városhálózatában a szabad királyi városoktól a NUTS régióközpontokig. Tér és Társadalom 23. évf. 2009/2. 97-111. p.

TÉT XXIII. évf. 2009 - 2

Tértörténet

107

ellenállása végül is a korábban kialakult területi struktúrának megfelelő városkörnyéki beosztást eredményezett.

1985-ben sor került az OTK módosítására (12/1980-85. OGY határozat), melynek okai elsósorban gazdasági megfontolásokon alapultak, területfejlesztési vonatkozása kevésbé érvényesült ( $P$ álné Kovács 2001). A módosítás megállapításai szerint az öt regionális funkciót betöltő város (Debrecen, Győr, Miskolc, Pécs és Szeged) extenzív fejlődését meg kell állítani, a mennyiségi fejlesztés helyett a felsőfokú szerepköreik bővítésére kell helyezni a hangsúlyt. Budapest csak a felsőfokú ellátásban legyen az ország kiemelkedóen legjelentősebb városa, szerepkörét inkább a nemzetközi városhálózatban kell erósíteni.

Az OTK módosításának közigazgatási - és településfejlesztési - szempontból egyik legfontosabb pontja megszüntette a települések kategorizálását, előre vetítve ezzel a hierarchikus besorolástól független önkormányzatiság megteremtését.

A rendszerváltozást megelőző utolsó módosítás a nagyvárosok státuszában 1989-ben történt, megyei város besorolást kapott valamennyi 100 ezer fónél népesebb város, így Kecskemét, Nyíregyháza és Székesfehérvár is.

\section{A rendszerváltozást követö közigazgatási reformok}

A rendszerváltozást követő időszakban újra értelmezésre került Magyarország közigazgatási struktúrája, annak vonatkozásában pedig a települések, városok és a megyék helyzete. Az 1990. évi Önkormányzati törvény egyfajta igazságszolgáltatás volt a települések részére a megyékkel szemben, ugyanakkor a rendszerváltozás elötti időszak területfejlesztésének - különösen az 1971-es Országos Településhálózat-fejlesztési Koncepciónak - kritikája. Leglényegesebb elemként végleg megszünt a közigazgatás hierarchikus rendszere, valamennyi önkormányzat (megyei és települési) egymással horizontális viszonyban álló önálló entitássá vált (Csefkó 1997). A középszintủ igazgatásban a megyei jogú városok a megyékhez hasonló jogosítványokkal lettek felruházva, hasonló feladatokat látnak el, differencia mindössze a területiségben érvényesül (Zongor 1999). A független önkormányzatú településekkel és a megyei közgyúlésekbe küldötteket sem küldő megyei jogú városok nélkül a megyék „súlytalanná” váltak (Pálné Kovács 1999).

Az 1990. évi önkormányzati törvényben és annak 1994. évi módosításában - a korábbiakhoz képest ugyan „demokratikus formában” és nem a fejlesztési irányok determinálása céljából - ismét megtörtént a városok kategorizálása (Szigeti 2002). Az elsö önkormányzati törvény valamennyi 50 ezer fönél népesebb várost megyei jogú városnak minősít (igaz nem automatikusan, hanem annak kérésére), de kiváltságok helyett a megyei önkormányzatoktól átvett, saját hatáskörben végrehajtandó feladatokat állapít meg. Az 1994. évi önkormányzati törvény módosítása értelmében az 50 ezer fơnél nem népesebb megyeszékhely városok is megyei jogú város státuszt kaptak. A kategória önmagában nem jelent pozitív diszkriminációt, a törvények értelmében nincs párhuzam a megyei jogú város státusz és a hierarchiából származó 
Csomós György : A regionális központok szerepének változása Magyarország városhálózatában

a szabad királyi városoktól a NUTS régióközpontokig. Tér és Társadalom 23. évf. 2009/2. 97-111. p.

108 Tértörténet

TÉT XXIII. évf. 2009

előnyök között. A népesség kategória megszabása alapvetően demokratikusnak tekinthetố és nem egyedi; a városoknak teljesíteniük kell egy kritériumot, vagyis el kell érniük a - magyar viszonylatok között - kritikus tömegnek számító népességküszöböt ${ }^{3}$.

A megyék „,kiürülésével" párhuzamosan felértékelödött a városok, és különösen a megyei jogú városok jelentősége, amelynek alapvetően két oka van. Egyrészt a megyei jogú városok minden vonatkozásban dominánsak megyéjükön belül, súlyuknál fogva kihagyhatatlanok a megyét érintő döntési és fejlesztési folyamatokból. Másrészt a megyei bázison szervezett dekoncentrált államigazgatási szerveknek a megyei jogú városok nyújtanak székhelyet, következésképpen a regionális keretek között létrehozott dekoncentrált (esetleg decentralizált) államigazgatási szervek központjai is optimális esetben a megyeszékhely - megyei jogú városok lehetnek (Szigeti 2003).

Közigazgatás szempontjából meghatározó a NUTS 2 régiók központjának kijelölése, tekintettel arra, hogy a regionális dekoncentrált (decentralizált) funkciók telepítése egyértelmủen a központokban valósul meg. Pálné Kovács Ilona szerint a régióközpont kijelölésének hiányában a régió városai között verseny alakul ki a regionális funkciók megszerzéséért, és a regionális szervezetrendszer nem szilárdulhat meg. A megyei jogú városok között az ,igazságosság” jegyében elosztott dekoncentrált szervezetek, a rotációs rendszerben müködő titkárságok, a regionális intézmények időszakonkénti költöztetése hosszabb távon még azoknak a városoknak sem kedvez, amelyek átmeneti előnyökhöz jutnak (Pálné Kovács 2001).

A nemzetközi - elsősorban a francia decentralizációs törekvésekre alapozott - területfejlesztési gyakorlat szerint akkor lehet versenyképes, erős régiókat szervezni, ha azok központjában a régió egészét dinamizálni képes nagyváros van (Perroux 1955; Pálné Kovács 1992; Bernek-Süli-Zakar 1997).

Bartke István véleménye szerint a régiók közigazgatási központjainak a növekedési pólusokat kell kijelölni. Gazdasági-társadalmi szempontból Budapest ellenpólusainak mindössze öt város minősíthető, Debrecen és Szeged önállóan, Győr, Miskolc és Pécs pedig az agglomerációs területükkel együtt. Elméletben más százezres városok is pólusvárosnak definiálhatók (Kecskemét, Nyíregyháza, Székesfehérvár), de a fejlesztésre rendelkezésre álló források megosztása veszélyeztetné a hatékonyságot (Bartke 2007).

Az 1998-ban elfogadott Országos Területfejlesztési Koncepció rögzítette a NUTS régiók kialakításának területi kereteit, de nem határozta meg a régióközpontokat. A 2005-ben átdolgozott és aktualizált formában elfogadott Országos Területfejlesztési Koncepcióban már megjelentek a növekedési pólusok (önállóan Debrecen, Győr, Miskolc, Pécs és Szeged, társközpontokként Székesfehérvár és Veszprém), azonban régióközpontok továbbra sem kerültek említésre.

Beluszky Pál 1996-ra vonatkoztatva vizsgálta a városok komplex típusait (5. táblázat). A városi funkciók súly alapján Debrecen, Pécs és Szeged teljes értékü regionális központ, Miskolc és Györ pedig hiányos szerepkörü regionális központ. Székesfehérvár ebben a vonatkozásban sorrendileg ugyan a hatodik város, azonban nem éri el a regionális központok súlyát (Beluszky 2003). 
Csomós György : A regionális központok szerepének változása Magyarország városhálózatában

a szabad királyi városoktól a NUTS régióközpontokig. Tér és Társadalom 23. évf. 2009/2. 97-111. p.

TÉT XXIII. évf. 2009 a 2

Tértörténet

109

\section{TÁBLÁZAT}

Komplex várostípusok hierarchikus rangsora a városi funkciók súlya alapján 1996-ban (Hierarchical Rank of Complex City Types on the Basis of the Weight of Civic

Functions, 1996)

\begin{tabular}{ccc}
\hline Sorrend & Város & Hierarchiaszint \\
\hline 1. & Debrecen & regionális központ \\
2. & Szeged & regionális központ \\
3. & Pécs & regionális központ \\
4. & Miskolc & hiányos szerepkörü regionális központ \\
5. & Györ & hiányos szerepkörü regionális központ \\
6. & Székesfehérvár & megyeközpont \\
14. & Veszprém & megyeközpont \\
\hline
\end{tabular}

Forrás: Beluszky (2003).

Beluszky Pál és Győri Róbert szerint 2000-ben öt város tekinthető regionális központnak - Debrecen, Györ, Miskolc, Pécs és Szeged - hasonló hierarchikus sorrendben, mint azt a korábbi vizsgálatok megállapították (Beluszky-Győri 2006).

A 2006-ban elfogadott Új Magyarország Fejlesztési Terv a 2005-ben megjelent Országos Területfejlesztési Koncepció alapján öt várost nevez meg önállóan pólusvárosnak, Debrecent, Györt, Miskolcot, Pécset és Szegedet, társközpontokként pedig Székesfehérvárt és Veszprémet. A fejlesztési tervekkel ellentétben a megyei közigazgatási hivatalok regionális szintre helyezéséről szóló 297/2006. kormányrendelet Pécs helyett Kaposvárt, Miskolccal szemben pedig Egert jelöli meg, mint a NUTS 2 régiók közigazgatási központjait.

Jelen állapot szerint a NUTS 2 régiók regionális centrumai (és egyben a fejlesztési pólusvárosok) meghatározottak, csakúgy, mint a régiók közigazgatási központjai. A decentralizáció felé vezető kővetkező lépés a regionális önkormányzatok székhelyeinek meghatározása, vagyis a régiók tényleges központjainak kijelölése lehet.

\section{Jegyzetek}

\footnotetext{
${ }^{1}$ A magyar kormány 2006-ban fogadta el az Új Magyarország Fejlesztési Tervet (ƯMFT), amely az Európai Unió 2007 és 2013 közötti 7 éves programozási időszakának hazai stratégiai referenciakerete. Az UMFT területfejlesztési vonatkozása kiemelt prioritásként kezeli a regionális központok pólus várossá fejlesztését elsösorban azzal a céllal, hogy oldják Magyarország túlzott Budapest centrikusságát. Az ellenpontot jelentỏ pólusvárosok az ÚMFT szerint Debrecen, Györ, Miskolc, Pécs és Szeged, valamint társközpontokként Székesfehérvár és Veszprém, vagyis az OTK 1971 -es megalkotásához képest több mint 30 év alatt a területfejlesztés vonatkozásában jelentős eredményt nem sikerült elérni.
} 
${ }^{2}$ Bibó István területi egységekkel kapesolatban megfogalmazott gondolatai párhuzamba állíthatók a NUTS rendszer regionális szerkezetének kialakitásával, mely szerint a területi struktúrában korábban nem létezett közigazgatási egységeket az egy szinttel kisebb egységek összevonásával kell létrehozni.

${ }^{3}$ Szekszárd, mint Tolna megye székhelye az 1994. évi Önkormányzati törvény módositásának értelmében alanyi jogon számít megyei jogú városnak, miközben lakossága 2006-ban nem érte el a 35 ezer föt. Bács-Kiskun megyében Baja több mint 37 ezer lakosával nem nyerte el ugyanazon státuszt. Ennek alapvető oka - a törvényt önmagában értelmezve - kizárólag a lakosságszámban keresendó. Amennyiben egy város lakossága nem éri el az 50 ezer föt, és nem megyeszékhely, nem lehet megyei jogú város. Hódmezővásárhely lakossága 1996-ban 50 ezer fö́ alá esökkent (2006-ban 47485 fö), és mivel nem megyeszékhely a törvény értelmében nem lehetne megyei jogú város. Ellentétes folyamat történt Érden, ahol 1995-ben haladta meg a város lakossága az 50 ezer fö́t (2006-ban 62408 fó), azonban az Országgyúlés sorozatosan elutasította a megyei jogú város státuszra vonatkozó kérelmét, egészen 2006-ig.

\section{Irodalom}

Bartke I. (2007) A társadalom és a gazdaság települési (térbeli) koncentrálódása, ennek hatásai és megítélése. - Magyar Tudomány. 6. 730-739.o.

Bácskai V. (2006) Néhány gondolat a városhierarchia dualizmuskori átalakulásáról. - Györi R.-Hajdú Z. (szerk.) Kárpát-medence: Települések, tájak, régiók, térstruktúrák. Dialóg Campus Kiadó, PécsBudapest. 11-24. o.

Bácskai V.-Nagy L. (1984) Piackörzetek, piacközpontok és városok Magyarországon 1828-ban. Akadémiai Kiadó, Budapest.

Beluszky P. (1987) A középszintü igazgatás és hazánk térszerkezete. A Magyar Tudományos Akadémia Regionális Kutatások Központjának kutatási eredményei. 8. szám. MTA RKK, Pécs.

Beluszky P. (1990) Magyarország városhálózata 1900-ban. - Tóth J. (szerk.) Tér-idó-társadalom. Huszenegy tanulmány Enyedi Györgynek. MTA RKK, Pécs. 93-129. o.

Beluszky P. (2003) Magyarország településfóldrajza (Általános rész). Dialóg Campus Kiadó, Budapest-Pécs.

Beluszky P. (2005) Magyarország történeti földrajza. I. kötet. Dialóg Campus Kiadó, Budapest-Pécs.

Beluszky P.-Györi R. (2006) A magyar városhálózat funkcionális versenyképessége. - Horváth Gy. (szerk.) Régiók és települések versenyképessége. MTA RKK, Pécs. 236-294. o.

Bernek Á.-Süli-Zakar I. (1997) Régiók, regionális folyamatok a világgazdaságban. Régiók a földrajzi térben. - Tér és Társadalom. 4. 85-104. o.

Bibó I. (1975) Közigazgatási területrendezés és az 1971. évi településhálózat-fejlesztési koncepció. MTA Igazgatástudományi Bizottsága Közigazgatástudományi Szekció, Budapest.

Csefkó F. (1997) A helyi önkormányzati rendszer. Dialóg Campus Kiadó, Budapest-Pécs.

Dövényi Z. (2003) Településrendszer. - Perczel Gy. (szerk.) Magyarország társadalmi-gazdasági földrajza. ELTE Eötvös Kiadó, Budapest. 521-564. o.

Erdei F. (1939) Magyar város. Athenaeum, Budapest.

Frisnyák S. (1995) Magyarország történeti földrajza. Nemzeti Tankönyvkiadó, Budapest.

Györffy Gy. (1997) Pest-Buda kialakulása. Akadémiai Kiadó, Budapest.

Hajdú Z. (1989) Az 1956-os közigazgatási területbeosztási reformterv földrajzi kérdései. - Tér és Társadalom. 3. 43-61. o.

Hajdú Z. (1992) Település- és településhálózat-fejlesztési politika Magyarországon az államszocializmus időszakában. - Földrajzi Közlemények, 1-2. 29-37.o.

Hajdú Z. (1993) A magyar megyerendszer történeti, területi fejlödésének sajátosságai (I. rész). Comitatus. 1. 56-62. o.

Hajdú Z. (1996) A közigazgatási térfelosztás változásai Magyarországon. - Tér és Társadalom. 1. 5-20. o.

Hajdú Z. (2005) Magyarország közigazgatási földrajza. Dialóg Campus Kiadó, Budapest-Pécs.

Kaffka P. (1932) Országrendezés. - Magyar Szemle. 2. 164-172. o.

Kaffka P. (1933) Az országrendezés mérnöki megvilágításban. - Magyar Szemle. 2. 209-217. o.

Kolozsváry V.-Szamel L. (1950) A járások területének rendezése. - Allam és Közigazgatás. 6-7. 45 1-465. o.

Kovács E.-Katus L. (szerk.) (1987) Magyarország története 1848-1890. Akadémiai Kiadó, Budapest.

Palotás Z. (1990) A trianoni határok. Interedition, Budapest.

Pálné Kovács I. (1992) Gondolatok egy lehetséges folyamatról, egy perifériafőváros születése: Lyon? Tér és Társadalom. 3-4. 291-293. o. 
Pálné Kovács I. (1999) Régiók az ezredfordulón? A terhes örökség és a jövő modernizációs kihívásai. Tér és Társadalom. 3. 59-77. o.

Pálné Kovács I. (2001) Regionális politika és közigazgatós. Dialóg Campus Kiadó, Budapest-Pécs.

Perroux, F. (1955) Note sur la notion de 'pôle de croissance'. - Économie Appliquée. 8. 307-320. o.

Rechnitzer J. (1998) Területi stratégiák. Dialóg Campus Kiadó, Budapest-Pécs.

Rónai A. (1989) Térképezett történelem. Magvetö Könyvkiadó, Budapest.

Szigeti E. (2002) Község, város, jogállás. (A magyar telepuiléshálózat közigazgatási térszerkezetének néhány kérdése.) Magyar Közigazgatási Intézet, Budapest.

Szigeti E. (2003) Az államigazgatás dekoncentrált területi szervezetrendszere regianalizálásának kérdései. Magyar Közigazgatási Intézet, Budapest.

Zongor G. (1999) Változatok a középszintre, avagy a magyar középszinttelenség. - Tér és Társadalom. 3. 45-58, o.

Vonatkozó rendeletek:

1848. évi XVI. törvénycikk a megyei hatóság ideiglenes gyakorlásáról

1848. évi XXIII. törvénycikk a szabad királyi városokról

1870. évi XLII. törvénycikk a köztörvényhatóságok rendezéséről

1872. évi XXXVI. törvénycikk Buda-Pest fővárosi törvényhatóság alakításáról és rendezéséről

1876. évi XX. törvénycikk némely törvényhatóságok megszüntetéséröl

1876. évi XXXIII. törvénycikk némely törvényhatóság területének szabályozásáról és az ezzel kapcsolatos intézkedésekröl

1877. évi I. törvénycikk némely törvényhatóságok véglegesen megállapított területének az 1876. évi XXXIII. tc. rendelkezése folytán törvénybe iktatásáról

1886. évi XXI. törvénycikk a törvényhatóságokról

1892. évi XXVI. törvénycikk a törvényhatóságokról szóló 1886 . évi XXXIII. tc. némely rendelkezéseinek módosításáról

1950. évi I. törvény a helyi tanácsokról

1971. évi I. törvény a tanácsokról

1990. évi LXV. törvény a helyi önkormányzatokról

1994. évi LXIII. törvény a helyi önkormányzatokról szóló 1990. évi LXV. törvény módosításáról

1007/1971. (III. 6.) Korm. sz. határozat az Országos Településhálózat-fejlesztési Koncepcióról

12/1980-85. OGY határozat az Országos Településhálózat-fejlesztési Koncepció módosításáról

35/1998. (III. 20.) OGY határozat az Országos Területfejlesztési Koncepcióról

97/2005. (XII. 25.) OGY határozat az Országos Területfejlesztési Koncepcióról

297/2006. (XII. 23.) Kormányrendelet a közigazgatási hivatalokról 